PRZEGLĄD NAUK HISTORYCZNYCH 2019, R. XVIII, NR 2

http://dx.doi.org/10.18778/1644-857X.18.02.11

\title{
Zwizualizowany imperializm i narodowa identyfikacja. Kilka przykładów kościelnego malarstwa w Gruzji od 1801 do 1918 roku ${ }^{1}$
}

Streszczenie. W różnych okresach chrześcijańskie malarstwo naścienne wizualizowało różnoraki stosunek do programów, obrazów, ikonografii i było blisko połączone $z$ religijna identyfikacja społeczeństwa. Pod wpływem rozwoju nacjonalizmu w Gruzji w połowie XIX w. malarstwo naścienne również zaczęło odpowiadać potrzebom identyfikacji narodowej. Ramy czasowe artykułu zakreślają najważniejsze wydarzenia $z$ historii tego kraju, takie jak podbój Wschodniej Gruzji przez Imperium Rosyjskie w 1801 r. i proklamowanie niepodległości przez Demokratyczną Republikę Gruzji w 1918 r. Pomiędzy tymi dwoma wydarzeniami w Gruzji powstało wiele malowideł sakralnych. Niektóre z nich miały na celu promowanie poczucia przynależności do Rosji i służyły konsolidacji władzy imperium nad podbitym krajem. Inne odzwierciedlały idee i aspiracje gruzińskiego nacjonalizmu. Różniły się one od średniowiecznych realizacji, ukazując wzrastajacce zainteresowanie narodowymi świętymi i wydarzeniami $z$ historii gruzińskiego chrześcijaństwa. W artykule omówiono najbardziej znaczące ich przykłady.

Słowa kluczowe: sztuka nowożytna, sztuka chrześcijańska, kościelne malarstwo naścienne, studia postkolonialne, odrodzenie narodowe.

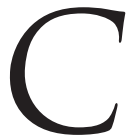

hwała Kościoła Gruzji to tytuł ikony przedstawionej na ilustracji 1. Została ona po raz pierwszy wydrukowana metoda chromolitografii w Lipsku w 1889 r., a następnie w Berlinie w roku 1895. Przykuwajace wzrok widza ideologiczne i kompozycyjne

* George Chubinashvili National Research Centre for Georgian Art History and Heritage Preservation, e-mail: tamtaxosro@gmail.com

${ }^{1}$ Praca powstała dzięki wsparciu Narodowej Fundacji Nauki im. Szoty Rustawelego w Gruzji (SRNSFG), grant nr: PhD_F_17_153. Projekt zatytułowany: „Malarstwo eklezjalne w Gruzji od 1801 do 1918 r." 


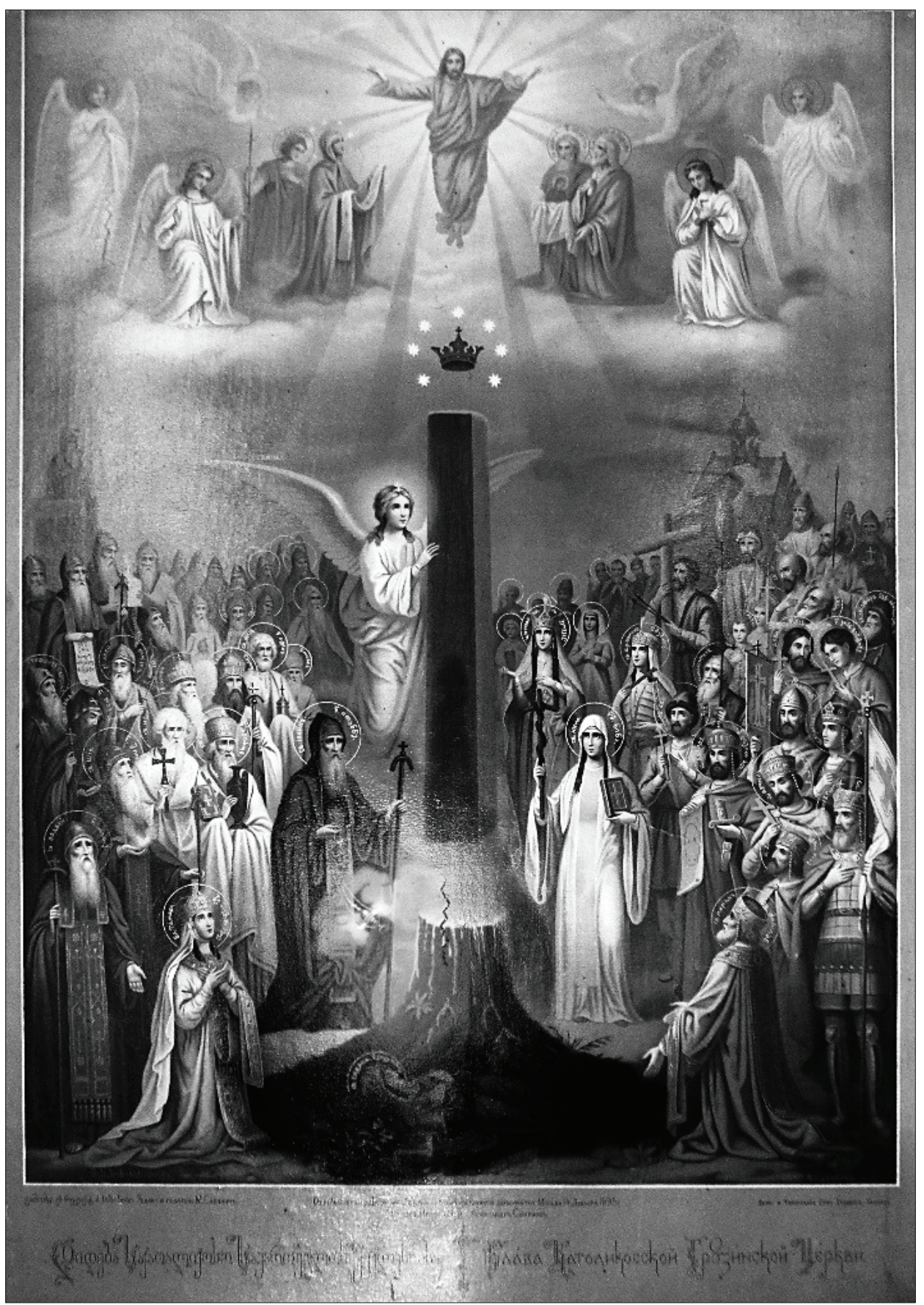

1. Ikona Chwała Kościoła Gruzji, chromolitograf, Berlin, 1895 r. 
centrum wieloosobowego układu ikony stanowi przedstawienie „życiodajnego filaru" unoszonego przez anioła nad grobem kobiety. To legendarne wydarzenie jest jednym $z$ najważniejszych i najcudowniejszych momentów w gruzińskim chrześcijaństwie i jest związane $z$ życiem świętej Niny $z$ Kapadocji, Oświecicielki Gruzji, żyjącej w IV w. Prawie we wszystkich przypadkach kompozycja przedstawiająca wniebowstapienie „życiodajnego filaru” opowiada nie tylko o wydarzeniach $z$ życia św. Niny, lecz także prezentuje wielowiekowa historię chrześcijaństwa w Gruzji. Ikona Chwała Kościoła Gruzji ukazuje zarówno swiętych biorących udział w tych wydarzeniach, jak i gruzińskich świętych $z$ innych epok. Stojacych $z$ przodu można zidentyfikować dzięki inskrypcjom na ich aureolach, podczas gdy $z$ tyłu zostali umieszczeni bezimienni święci, prawdopodobnie traktowani jako reprezentanci wszystkich gruzińskich świętych. Historia ukazana na ikonie, obejmująca wszystkie postaci i ich znaczenie, prezentuje całą historię chrześcijaństwa w Gruzji od pierwszych wieków do czasów powstania ikony.

Pozwolę sobie zwrócić uwagę na inskrypcję zamieszczona poniżej ikony. Większa i pogrubiona część tekstu to dwujęzyczny tytuł, zapisany w językach gruzińskim i rosyjskim - Chwała Kościoła Gruzji. $Z$ tyłu, za tytułem można zauważyć inny napis, tym razem jedynie w języku rosyjskim: „Drukowanie dozwolone przez Teologiczny Komitet Cenzury w Moskwie”. Dalsza część tekstu, zapisana z użyciem złotych liter, głosi: „Pamięci niezapomnianego i świętego cesarza Aleksandra Aleksandrowicza, wdzięczny autor, wydawca".

Imiona umieszczone na aureolach świętych również są dwujęzyczne - gruzińskie i rosyjskie. Nie ulega wątpliwości, że ta specjalna ikonografia, prezentująca przeszłość gruzińskiego Kościoła, ale połączona $z$ rosyjskimi inskrypcjami, musiała wynikać $z$ konkretnych uwarunkowań. Od początku wieku XIX aż do 1918 r. kraj pozostawał rosyjska prowincja. Po zdobyciu wschodniej Gruzji w 1801 r. rosyjskie władze zlikwidowały autokefalię gruzińskiego Kościoła i zastapiły patriarchę Kościoła gruzińskiego rosyjskim egzarchą. Następnie zakazano używania języka gruzińskiego w szkołach i kościołach.

W tym okresie zbudowano i ozdobiono w Gruzji wiele świątyń. Część z nich miała promować idee zespolenia podbitego kraju $z$ imperium rosyjskim i wspierać dążenia władz carskich do utrwalenia tu swojego panowania. Inne zaś odzwierciedlały idee i aspiracje gruzińskiego nacjonalizmu. Różniły się one od dzieł 
średniowiecznych, ukazując wzrastające zainteresowanie gruzińskich elit narodowymi świętymi i wydarzeniami $z$ dziejów chrześcijaństwa w Gruzji. Możemy wskazać świątynie, w wystroju których odnajdujemy zarówno imperialne, jak i narodowe idee. W prezentowanym tu szkicu skupię się na najbardziej znaczących przykładach.

Pierwszą świątynią, której wystrój w całej rozciągłości podporządkowano koncepcji promującej rosyjską ideę imperialną, jest wojskowa katedra w Tbilisi pw. św. Aleksandra Newskiego, zbudowana w 1898 r. i wyburzona przez władze sowieckie w 1930 r. $^{2}$ Według czasopisma "Caucasus" fundamenty katedry zostały poświęcone 16 kwietnia $1871 \mathrm{r}$. W ceremonii osobiście uczestniczył cesarz Aleksander II. Fundamenty ozdobiono kwiatami, flagami i sprzętem wojskowym. Pod flagami umieszczono płyty $z$ wygrawerowanymi nazwiskami rosyjskich dowódców, którzy zasłużyli się w podboju Kaukazu. Na niektórych płytach ukazano epizody $z$ bitew toczonych na tym terenie. Egzarcha Evseby przewodniczył liturgii i umieścił wewnątrz fundamentów po jednym egzemplarzu srebrnych i złotych monet wybitych w roku poświęcenia świątyni. Dwie $z$ tych monet uwieczniały ujarzmienie Czeczenii i Dagestanu przez Rosję. W fundamentach znajdowała się również ogromna płyta $z$ inskrypcją: „Kościół ten jest postawiony ku pamięci zwycięstwa w Kaukazie"3. Budowa trwała 26 lat. Wojskowa katedra pw. św. Aleksandra Newskiego została wzniesiona w stylu bizantyńskim, tak popularnym $\mathrm{w}$ imperium rosyjskim. W owym czasie Rosja próbowała realizować swoje wielkie plany imperialne. Koncepcja restauracji cesarstwa bizantyńskiego, skupiającego pod berłem carów wszystkich wyznawców prawosławia, zawsze mogła liczyć na wsparcie elit politycznych Petersburga i Moskwy.

Malowidła naścienne i nowa dekoracja prezbiterium (il. 2) katedry Sioni w Tbilisi również zostały stworzone w stylu neobizantyńskim przez rosyjskiego malarza, hrabiego Grigorija Gagarina na poczatku lat pięćdziesiątych XIX w. Rosyjski hrabia Sołohub opisywał je w następujący sposób: „W sercu Kaukazu, w Tbilisi, jest odrestaurowywana wspaniała katedra... Możemy to nazwać

2 „Iveria” 1897, № 98; „Tsnobis furtseli” 1897, № 205; „Kavkaz” 1897, № 133; „Komunisti” 1930, № 31; V. Beridze, Tbilisis Khurotmodzgureba, 1801-1917, vol. II, Tbilisi 1963, s. 66-67. Transliteracja języka gruzińskiego i rosyjskiego w wersji angielskiej (przyp. tłumacza).

3 „Kavkaz” 1871, № 34 . 
nie tylko kamieniem milowym dla lokalnej historii, ale przełomem dla sztuki rosyjskiej. Katedra jest odnawiana w ascetycznym bizantyńskim stylu. Bizantyjska architektura, która od dawna jest zakorzeniona na Kaukazie, jest bardzo ważna dla nas, Rosjan, jako oryginalny symbol rosyjskiego Kościoła. Tak więc katedra Sioni jest symbolem uświęconej unii dwóch narodów, odrestaurowana po wielu wiekach, należy nie tylko do Gruzinów, lecz także do Rosjan"4.

Duch rosyjskiego imperializmu jest wyraźnie widoczny również w malowidłach w kościele pw. św. Trójcy w Tbilisi (il. 3), gdzie poza wizerunkami gruzińskich świętych można zauważyć również świętych rosyjskich ${ }^{5}$, m.in. Aleksandra Newskiego, Włodzimierza Wielkiego, Sergiusza z Radoneża i innych. Jednak specjalna uwaga jest skierowana na przedstawienia świętych Cyryla i Metodego. Tych dwóch świętych $z$ Tesaloniki nie było w żaden sposób powiązanych $z$ Gruzja, jednak ich zasługi dla Rosji sa niezaprzeczalne - stworzyli oni słowiański alfabet. Święci zostali umieszczeni w dość widocznym miejscu, w południowym i północnym skrzydle między scenami biblijnymi. Najwyraźniej obecność wizerunków Cyryla i Metodego oraz ich lokalizacja były celowym zabiegiem, mającym ukazać wyższość Kościoła rosyjskiego nad gruzińskim. Pojawienie się wizerunków rosyjskich świętych w kościele pw. św. Trójcy jest wyraźnym, jaskrawym przejawem tendencji do akcentowania zwierzchnictwa rosyjskiego Kościoła nad Kościołem gruzińskim. Jednakże przeciwko tej imperialnej propagandzie występowali twórcy wyrażający gruzińskie aspiracje narodowościowe. Można tu przywołać chociażby pojawienie się inskrypcji zapisanych nie w języku rosyjskim (tak jak w malowidłach w kościele Sioni), lecz po gruzińsku, w piśmie nuschuri. Mimo że na omawianym tu obrazie sa przedstawieni rosyjscy święci, to pozostaja oni w mniejszości, gdyż malowidło zdominowane jest przez grupę świętych gruzińskiego Kościoła narodowego - podobnie jak w wejściu do kościoła pw. św. Trójcy, gdzie jeden rosyjski święty jest witany przez liczna grupę świętych gruzińskich i to właśnie na nich

${ }^{4}$ P. Ios eliani, Agstera tfilisis sidzveleta, Tbilisi 2009, s. 1005-1010.

${ }^{5}$ Kościół pw. św. Trójcy został udekorowany przez włoskiego artystę Ludviga Longo, który pracował w Tbilisi w latach 1890-1910. Prowadził on w Gruzji również działalność pedagogiczną. Na temat L. Londo por. M. Tsits is hvili, N. Chogos hvili, Qartuli mxatvrona, ganvitarebis istoria (XVIII-XIX saukuneebshi), s. 275-276, Narodowe Archiwum Gruzji, karton 489, 42794. 


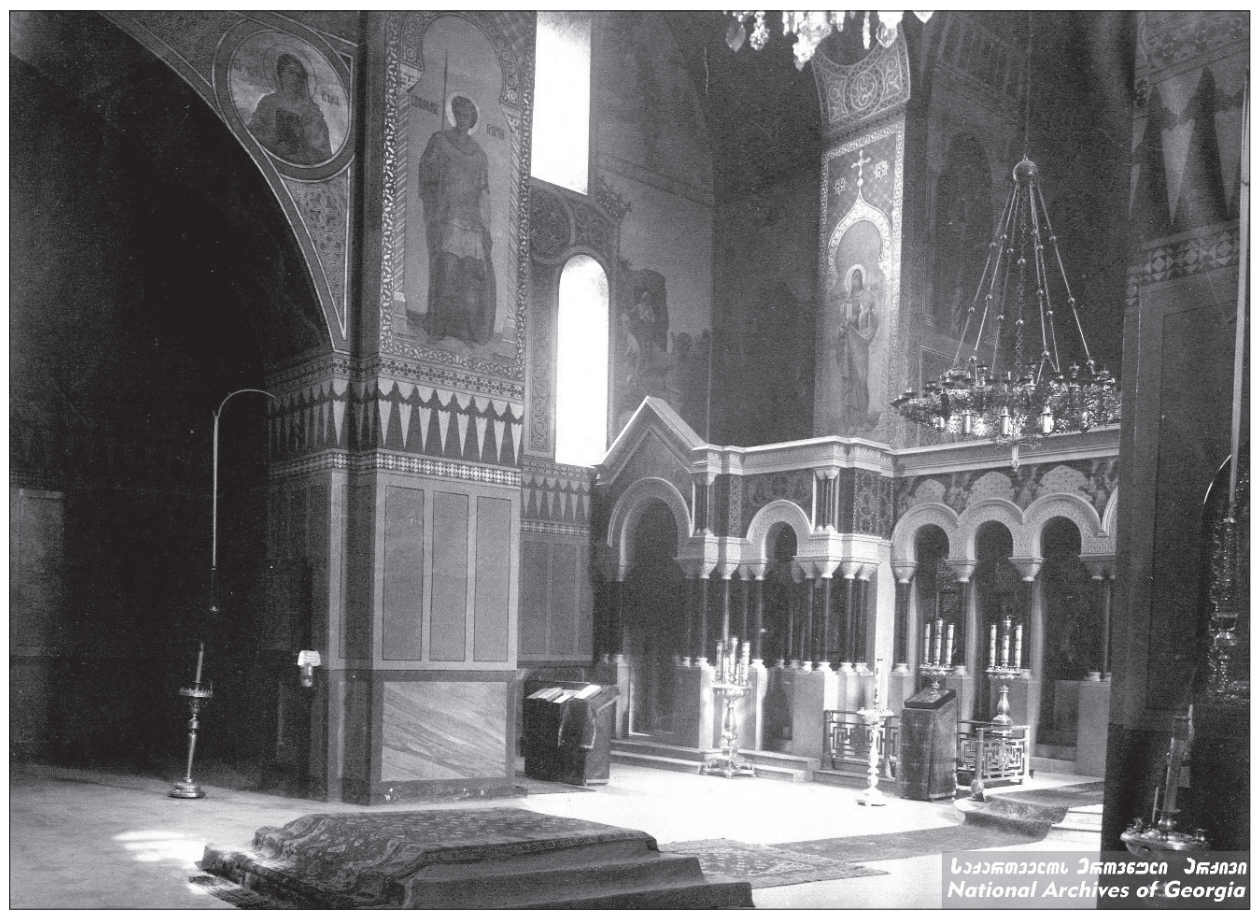

2. Wnętrze i widok na prezbiterium w kościele Sioni, poł. XIX w., fot. D. Ermakov, około 1900 r. (Narodowe Archiwum Gruzińskie)

skupia się uwaga odbiorcy. Narodowymi elementami wystroju świątyni sa ponadto: ogromny wizerunek królowej Tamary i wybitnego poety Szoty Rustawelego, na wschodnim pilastrze wspierajacym kopułę. Tamara panowała na przełomie XII i XIII w., a okres jej rządów był czasem bardzo pomyślnym dla Gruzji. Szota Rustaweli był $z$ kolei współczesnym jej poeta, autorem eposu Rycerz $w$ tygrysiej skórze. $Z$ pewnościa przedstawienie tych dwóch postaci, które były symbolem niegdyś potężnej i zjednoczonej Gruzji, stanowiło odzwierciedlenie patriotycznych tendencji w sztuce kościelnej, niemniej jednak dziwić może umieszczenie w tak ważnym miejscu wizerunku poety, który nigdy nie został uznany za świętego. Trzeba wyraźnie zaznaczyć, że w XIX w. Szota Rustaweli stał się symbolem narodowej tożsamości Gruzinów. Kościół pw. św. Trójcy był przyozdabiany w latach dziewięćdziesiątych XIX w., kilka lat po ukazaniu się nowej edycji jego dzieł. Pomysł opracowania nowego wydania Rycerza $w$ tygrysiej skórze został zaprezentowany na łamach gazety „Droeba” w roku 1880 przez grupę gruzińskich 


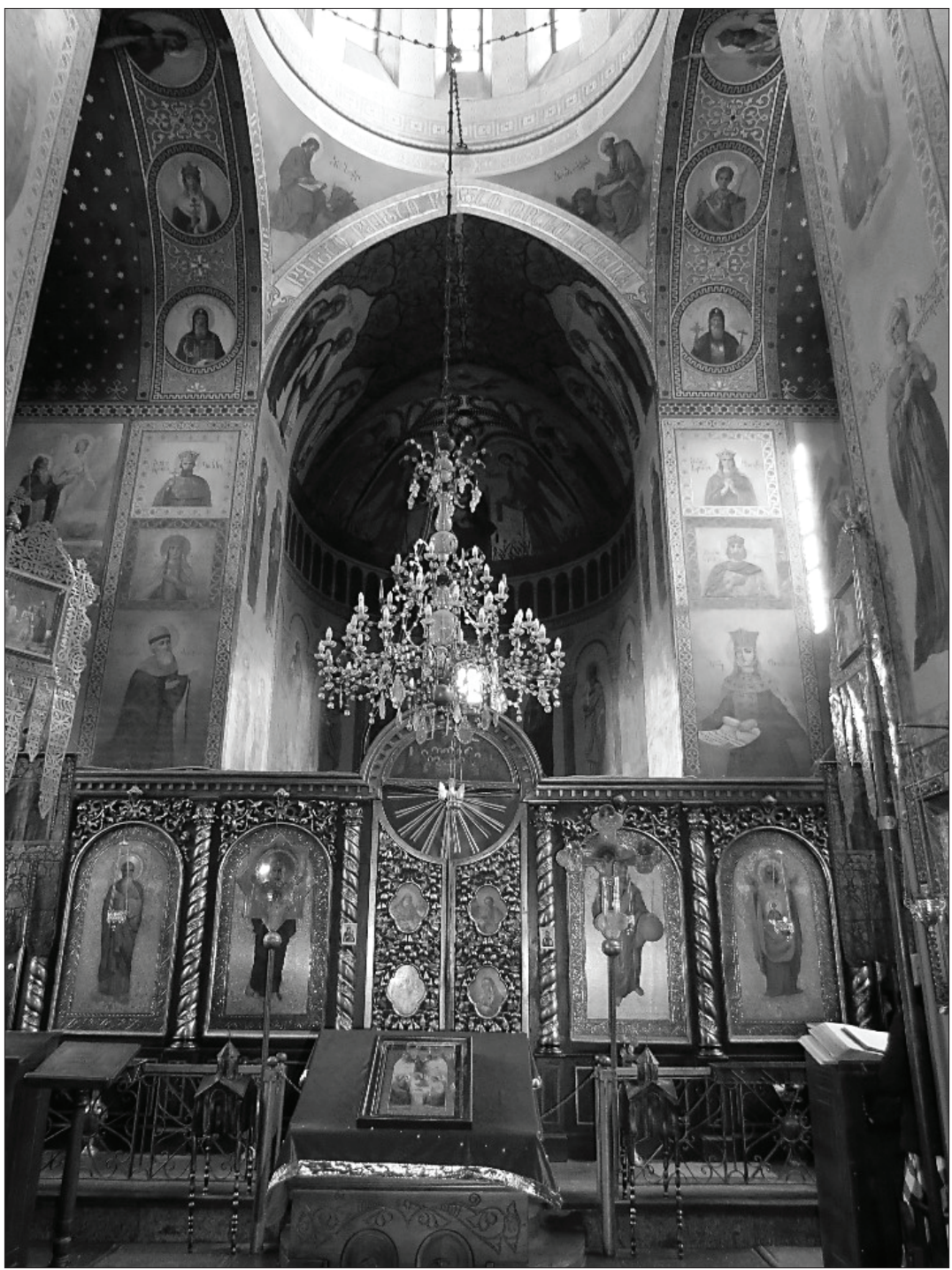

3. Wnętrze kościoła pw. św. Trójcy w Tbilisi, Gruzja, 1895 r.

intelektualistów: „Zamierzamy przygotować drukowaną wersję $R y$ cerza $w$ tygrysiej skórze $z$ jego manuskryptu... Jednakże nie śmiemy brać na siebie odpowiedzialności związanej $z$ wydaniem tak ważnego dzieła. Chcielibyśmy, aby każdy, kto traktuje Rustawelego jako nieoceniony skarb narodowy, wziął w tym udział"6.

${ }^{6}$ Vepkhistkaosnis redawcia, „Droeba” 1880, № 241. 
Autorzy artykułu zwracali się do członków Towarzystwa Rozpowszechniania Literatury wśród Gruzinów o zaangażowanie się w proces przygotowywania nowej edycji i apelowali do gruzińskiego społeczeństwa o wypożyczenie redaktorom starszych edycji Rycerza $w$ tygrysiej skórze, aby dokonać porównania $z$ dotychczasowymi wydaniami i przygotowania nowej, krytycznej edycji poematu. Przedstawiony tu pomysł spotkał się z odzewem już następnego dnia: „We wczorajszym numerze mogliście państwo przeczytać ogłoszenie podpisane przez trzy osoby, które obwieściły, że zostanie utworzony zespół redaktorów w celu poprawienia błędów w naszym wspaniałym poemacie Rycerz $w$ tygrysiej skórze. Rustaweli jest naszym wielkim poeta, którego my, Gruzini, możemy bez wahania wychwalać. Od niepamiętnych czasów nasi przodkowie mieli dwa skarby, dwie święte księgi konsolidujące nas w dobrych i złych czasach: były to Biblia i Rycerz $w$ tygrysiej skórze. Jedna odzwierciedlała nasze wyznanie i wiarę, druga nasza gruzińska tożsamość. Poprzednie pokolenia wychowywały się na tych dwóch książkach, one uczyniły ich odważnymi, gdy stawiali czoła problemom, z którymi musieli się zmierzyć w kraju i poza jego granicami... Każdy Gruzin musi trzymać te księgi w rękach, zawsze mieć je przy sobie i traktować jak relikwie... Jesteśmy zaszczyceni zaproszeniem inicjatorów utworzenia zespołu wydawniczego Rycerza $w$ tygrysiej skórze i jesteśmy przekonani, że każdy Gruzin zdolny do uczestnictwa w tym przedsięwzięciu okaże im swoja pomoc i pomoże udźwignać to ciężkie brzemię. To jest sprawa publiczna i jest obowiązkiem każdego wspomóc tych, którzy podjęli się tego jakże ważnego zadania"7.

Zespół redakcyjny zakończył prace nad tekstem w 1882 r. Grawer Grigol Tatishvili zlecił węgierskiemu artyście Mihálemu Zichy’emu zilustrowanie książki, podczas gdy sam podjął się ozdobienia brzegów kart i inicjałów. Ówczesny gruziński publicysta i krytyk Iona Meunargia napisał: „Zwyczajne zdobnictwo nie będzie odpowiednie do zapewnienia godnego ozdobienia Rycerza $w$ tygrysiej skórze. Zaistniała potrzeba znalezienia zupełnie nowego materiału do wykonania dekoracji. Taki materiał był dostępny jedynie w zabytkach gruzińskiej architektury. Tatishvili wykonał ilustracje wspaniałych gruzińskich ornamentów ze ścian, kopuł, krypt i pomników wykonanych $z$ prawdziwym artyzmem"s.

7 Vepkhistkaosnis redawcia, „Droeba” 1880, № 242.

${ }^{8} \mathrm{~S}$. Tsais hvili, Iona meunargias tserilebi, "Zugdidis sakhelmtsifo istoriul-etnografiuli shromebi” 1947, № 1, s. 26-37. 
Nie ulega więc wątpliwości, że przygotowanie nowego wydania Rycerza $w$ tygrysiej skórze miało na celu zachowanie narodowej tożsamości Gruzinów. Pojawienie się portretu Szoty Rustawelego w kościele pw. św. Trójcy wydaje się naturalnym następstwem opisanych wydarzeń. W czasach, gdy nie istniała gruzińska państwowość, Kościół gruziński pozbawiony był autokefalii, a tożsamość narodowa Gruzinów była zagrożona, wielki gruziński poeta został przedstawiony na ołtarzu kościoła pw. św. Trójcy. Warto również zwrócić uwagę na to, że wizerunek Szoty Rustawelego $\mathrm{w}$ tej świątyni jest kopia jedynego portretu poety, który dotrwał do czasów współczesnych - obrazu namalowanego w klasztorze pw. św. Krzyża w Jerozolimie. Co prawda artysta nadał jego twarzy bardziej trójwymiarowy charakter, ale już postawa i szaty ewidentnie nawiąuja do oryginalnego wizerunku znajdującego się $\mathrm{w}$ jerozolimskim klasztorze pw. św. Krzyża9. Ten sam twórca zdecydował się przedstawić wizerunek królowej Tamary w europejskim stylu, mimo że zachowało się pięć portretów władczyni wykonanych w średniowieczu. W wieku XIX powszechna praktyka było wymyślanie i „retuszowanie” różnych ikonograficznych wersji przedstawień świętych i postaci historycznych. Chociaż brano pod uwagę atrybuty, otoczenie i ubiór charakterystyczne dla ikonografii konkretnych swiętych obecne we wcześniejszych wersjach, to wiele elementów obrazu było wytworem wyobraźni artysty. W ten sposób ukazano świętych na ołtarzu kościoła pw. św. Trójcy. Jedynie Rustaweli został przedstawiony w sposób nawiązujący do wizerunku z kościoła jerozolimskiego. Fresk ukazujący Szotę Rustawelego dzięki samej swej obecności ożywia ideę potężnej i zjednoczonej Gruzji, która w czasach poety miała już swój własny klasztor w Ziemi Świętej, podczas gdy ówczesna Ruś dopiero wkraczała w trzecie stulecie od chwili przyjęcia chrześcijaństwa. Wizerunek świętych Cyryla i Metodego umieszczony na ścianie kościoła pw. św. Trójcy przypominać miał widzom o tym właśnie fakcie.

Malowidła naścienne $z$ kościoła pw. św. Dawida w Tbilisi powstały w tym samym czasie $(1889)^{10}$. Zgodnie $z$ tradycja Chrystus Pantokrator umieszczony został na kopule. W apsydzie znajduje się

${ }^{9}$ M. Didebulidze, D. Tumanishvili, Ancient Georgian Art, Tbilisi 2008, s. 52-54; S. A mirana s hvili, Qartuli khelovnebis istoria, Tbilisi 1951, s. 344-363; T. Virsaladze, Rospis ierusalimskogo krestnogo monastira I portret shota rustaveli, Tbilisi 1973.

10 Por. T. Khos roshvili, Mtatsmindis „mamadavitis” mokhatulobis taviseburebani, „Saqartvelos Sidzveleni” 2013, № 16, s. 198-213. 


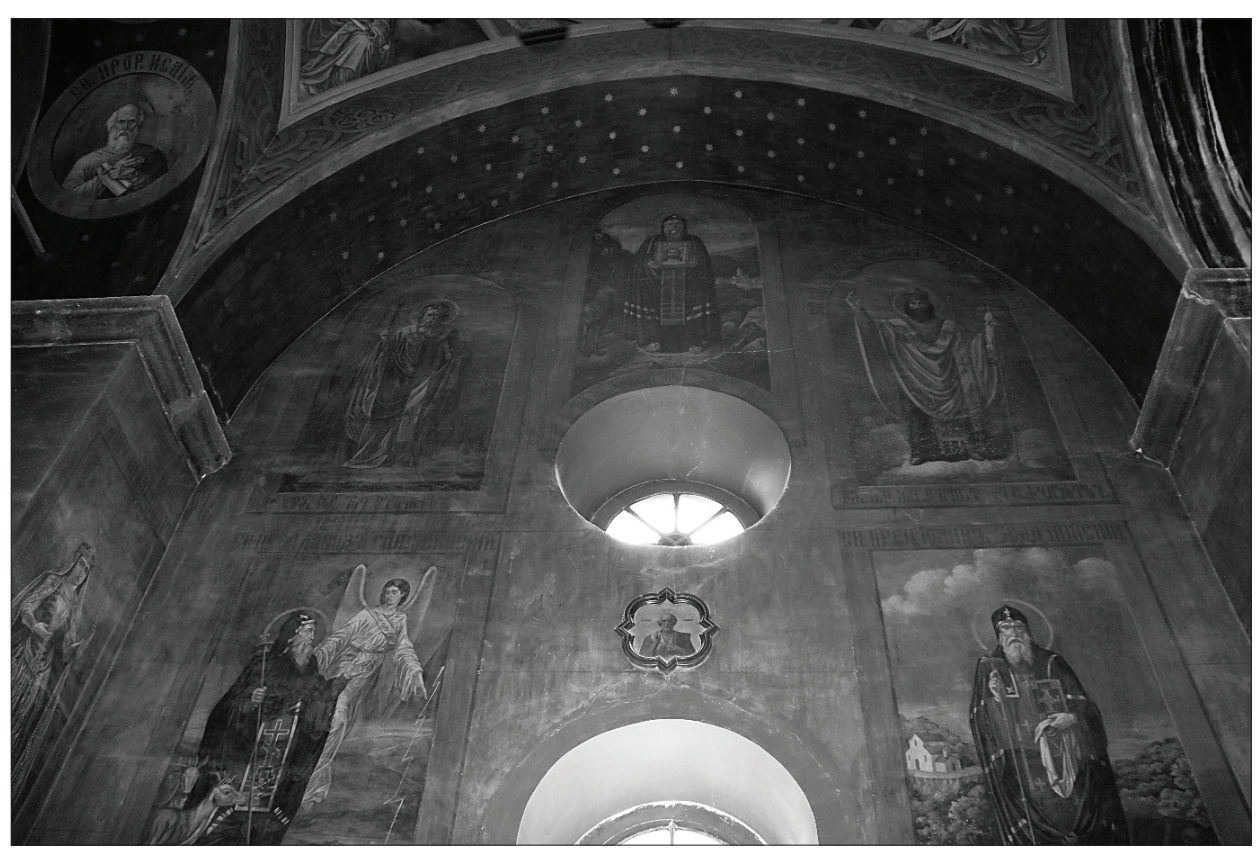

4. Malowidła naścienne przedstawiające gruzińskich świętych na południowej ścianie kościoła pw. św. Dawida w Tbilisi, Gruzja, 1889 r.

popularny wizerunek trójcy: Ojciec, Syn i Duch Święty, symbolizowany przez gołębicę, podczas gdy malowidła ołtarzowe przedstawiaja apostołów, a ambona Matkę Boską i proroków. Zwykle sceny $z$ Nowego Testamentu powinny znajdować się na pierwszym planie, ale ich nieobecność czyni kościół pw. św. Dawida wyjątkowym: na ścianach i pilastrach możemy zobaczyć freski $z$ gruzińskimi świętymi. W przeciwieństwie do fresków $z$ kościoła pw. św. Trójcy nie ma tu żadnych „obcych”, są wybitni Gruzini lub osoby ściśle związane $z$ tym krajem (il. 4).

Wizerunek każdego ze świętych powstał na podstawie ilustracji z niezwykle popularnej wówczas książki Gruziński Raj, opublikowanej w Petersburgu w 1882 r. przez Michaiła (Gobrona) Sabinina. Wcześniej, w latach 1871-1873, wydał on już inną, podobna książkę - pełny opis życia świętych Kościoła gruzińskiego w języku rosyjskim, w trzech tomach. Jest on również autorem ikony Chwała Kościoła Gruzji. 
Sabinin urodził się w Tbilisi w 1845 r., jego ojciec był klerykiem narodowości rosyjskiej ${ }^{11}$. Do Gruzji przybył $z$ Tweru, poślubił Gruzinkę i tutaj się osiedlił. Michaił początkowo kształcił się w klasycznym gimnazjum w Tbilisi, następnie kontynuował edukację w Akademii Religijnej w Petersburgu, gdzie uzyskał dyplom $z$ teologii. Jego praca dyplomowa była Historia gruzińskiego Kościoła przed VI $w$. Pod koniec nauki Sabinin przyjął święcenia kapłańskie i imię Gobron. Na pierwszych latach studiów rozwinęło się u niego zainteresowanie gruzińska historia. Odwiedzał wówczas gruzińskie kościoły i klasztory, zapoznawał się z przechowywanymi tam manuskryptami, oglądał stare ikony i relikwie, spisywał ustną tradycję przekazywana przez miejscowych. We wprowadzeniu do książki pisał: „Mój szanowny czytelniku, upadek Kościoła gruzińskiego zmotywował mnie do napisania tej książki, która zatytułowałem Gruziński raj. Nie ma innej książki, drukowanej czy rękopiśmiennej, podobnej do tej. Zawarte sa w niej wszystkie dostępne mi informacje. Błagam cię, mój szanowny czytelniku i słuchaczu, okaż sumienność i dodaj to wszystko, co możesz wiedzieć, tak by nasz święty język nie został zdesakralizowany... przez to, że jest wielu naszych krewniaków i obcych, którzy chcieliby zobaczyć zniszczenie naszego pięknego języka, który jest tak bliski Bogu"12.

Jak stwierdził Sabinin, szukał on żywotów świętych w gruzińskich manuskryptach $z$ różnych okresów, jednakże nie mógł znaleźć informacji o niektórych świętych, których uważał za najważniejszych, więc poczynił własne dodatki do zbioru. Warto odnotować, co autor uznał za najważniejsze do dodania: „nie było historii kilku wspomnianych powyżej świętych, którzy są niezwykle istotni dla mojego projektu: to Zaśnięcie Marii, jako że nasz kościół jest przeznaczony dla najświętszej panienki Marii; historii apostoła św. Andrzeja, który jako pierwszy modlił się Słowem; historii św. Jerzego, który zawsze był blisko związany ze św. Niną"13.

$\mathrm{Na}$ koniec autor, uniesiony patriotyzmem, zwrócił się do czytelnika ponownie: „Najlepiej, jak umiałem, uczciłem pamięć wszystkich w tej książce. Błagam cię, uczciwy czytelniku lub słuchaczu,

${ }^{11} \mathrm{Na}$ temat Michaiła Sabininiego por. V. Kiknadze, Erovnuli da sacatsobrio problematica meckhramete saucunis qartveli sasuliero mogvatseebis shemoqmedebashi, Tbilisi 2009, s. 272-325.

12 Saqartvelos samotkhe, ed. M. Sabinin, St Petersburg 1882.

13 Ibidem. 
jeśli jesteś świadomy czegoś więcej niż zawarte tutaj, bądź tak sumienny, by to dodać, aby nasz święty język, który jest wspominany przez ojców świętych i jest wyposażony w rozum duchowy i miłość, nie został zdeprawowany, aby nie stracić żywotów gruzińskich świętych. Jest wielu zarówno pośród nas, jak i obcych którzy chcieliby zniszczyć piękny ukochany przez Boga język"14.

Wstęp do Gruzińskich cudów jest otwartym manifestem inspirowanym ideami narodowościowymi. Widać tu dokładnie, że projekt malowideł $z$ kościoła pw. św. Dawida był inspirowany dziełem Sabininiego i że zostały one stworzone według zawartych w nim ilustracji.

W narodowym kontekście należy też rozpatrywać dekorację na łuku triumfalnym $z$ kościoła pw. św. Dawida, gdzie znajduje się wizerunek Matki Bożej (Theotokos), przedstawionej z cingulum ${ }^{15}$ w ręce (il. 5). Pas Maryi jest tym, co najbardziej przykuwa nasza uwage. Według legendy cingulum Dziewicy było przechowywane w Gruzji od XI w. Według jednej z wersji tej historii Helena, bratanica cesarza bizantyńskiego, przywiozła cingulum i ikonę Blachernitisy (Matki Boskiej z Blachernae) do Gruzji, kiedy poślubiła króla Bagrata IV ${ }^{16}$. Piętnastowieczne zagraniczne źródła wspominają, że pielgrzymi wędrujący w tamtym czasie w Ziemi Świętej nazywali Gruzinów „chrześcijanami od cingulum Matki Bożej”17. W XIX w. zarówno Gruzini, jak i zagraniczni uczeni podkreślali ten fakt. Na malowidle naściennym w kościele pw. św. Dawida Matka Boska $z$ pasem $w$ dłoniach wydaje się błagać o zmiłowanie nad ziemiami Gruzji, za których patronke jest uznawana. Dlatego też Dziewica była przez Gruzinów uznawana za symbol ich wiary i nadziei.

Analizując przekaz ikony Chwała Kościoła Gruzji, należy zwrócić uwage na górna jej część, $z$ unoszącym ramiona Jezusem w centrum, błogosławiącym gruzińskich świętych i „życiodajne filary”. Dziewica Maryja i św. Jerzy klęczą po jego prawicy, podczas gdy apostołowie Andrzej i Mateusz znajduja się po jego lewej stronie. Obrazy świętych Andrzeja i Mateusza były pierwotnie powiązane $z$ „życiodajnymi filarami”, gdyż święci ci przynieśli chrześcijaństwo do Gruzji, a św. Andrzej jest uważany za założyciela ortodoksyjne-

14 Ibidem.

${ }_{15}$ Cingulum Matki Boskiej to według tradycji Kościołów ortodoksyjnych pas, który wniebowzięta Maryja miała podarować św. Tomaszowi (przyp. tłumacza).

${ }_{16}$ Ikona jest obecnie przechowywana w gruzińskim Muzeum Narodowym.

17 E. Bubulas hvili, Saqartvelos eklesiis sitsmindeebi, Saeclesio Biblioteca, vol. VII, Tbilisi 2007, s. 153-169. 


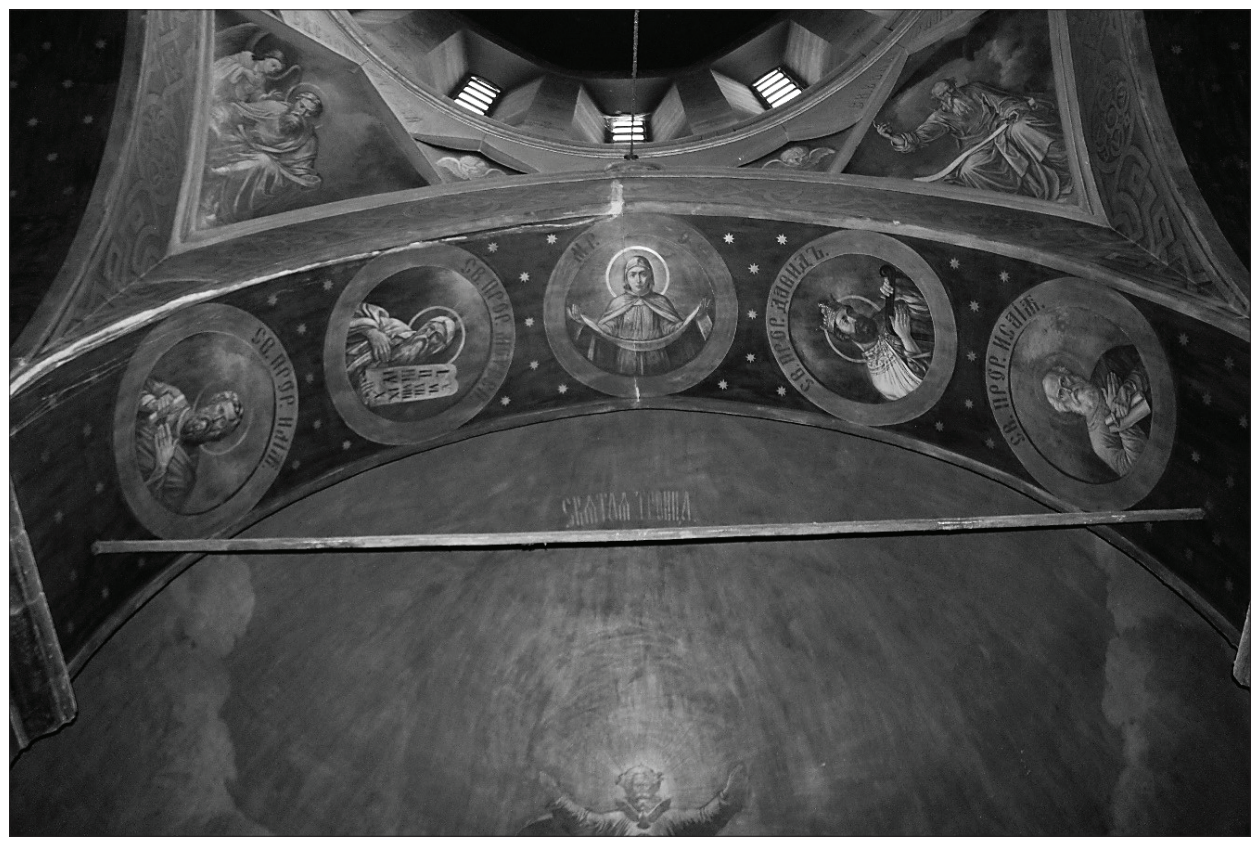

5. Maria Dziewica $z$ cingulum, łuk triumfalny $z$ kościoła pw. św. Dawida w Tbilisi, Gruzja, 1889 r.

go Kościoła Gruzji. Obecność św. Jerzego na ikonie nie jest przypadkowa. Gruziński Kościół wspomina go dwa razy w roku. Europejczycy w średniowieczu łączyli nazwę Gruzji właśnie $z$ tym świętym. Jego postać stanowi uniwersalna tematykę, która została przyjęta jako symbol narodowy i „lokalny”. Dziewica Maryja jest przedstawiona na ikonie $z$ cingulum $w$ dłoni!

Duch narodowego odrodzenia wzrastał w Gruzji w poczattkach XX w. i skutkował proklamowaniem niepodległości przez Demokratyczną Republikę Gruzji w 1918 r. Niestety jej krótki żywot zakończyła sowiecka inwazja w $1921 \mathrm{r}$.

$Z$ języka angielskiego przełożyła

Magdalena MaKówKa UNIWERSYTET ŁÓDZKI*

iD https://orcid.org/0000-0003-0447-832X

* Wydział Filozoficzno-Historyczny, Instytut Historii, Katedra Historii Nowożytnej, e-mail: magdalenamakowka@wp.pl 


\section{Bibliografia}

\section{$\dot{Z}_{\text {RÓDEA DRUKOWANE }}$}

Ioseliani P., Opisanie drevnostei goroda tiplisa, Tiflis 1866.

Sabinin M., Polnoe jizneopisanie sviatikh gruzinskoi cerkvi, vol. I-III, Saint Petersburg 1871-1873.

Saqartvelos samotkhe, ed. M. Sabinin, St Petersburg 1882.

\section{Prasa}

„Droeba” 1880.

„Iveria” 1897.

„Kavkaz” 1851, 1897.

„Komunisti” 1930.

„Tsnobis furtseli” 1897.

\section{OpRacowania}

Amiranashvili S., Qrtuli khelovnebis istoria, Tbilisi 1951.

Arqiteqtura da Identoba, saeklesio mshenebloba Tbilisshi (1801-1918), ed. D. Khoshtaria, Tbilisi 2016.

Beridze V., Tumanishvili D., Culture and Artistic life in the First Republic of Georgia (1918-1921), Tbilisi 2018.

Bubulashvili E., Saqartvelos eklesiis sitsmindeebi, Saeclesio Biblioteca, vol. VII, Tbilisi 2007.

Durilin S., Nesterov v Jizni I tvorchevstve, Moscow 1976.

Dzutsova I., Narodnoe Napravlenie v gruzinskoi stankovoi Jivopisi vtoroi polovini XVIII-XIX vekov, Tbilisi 2014.

Georgian Christian Art, Tbilisi 2010.

Hatt M., Klonk Ch., Art History - A Critical Introduction to its Methods, Manchester 2006.

Janjalia M., Bodbis tadzris egvteris mokhatuloba da misi literaturuli tskaroebi, saqartvelos ssr mecnierebata akademiis macne, „Istoriis seria” 1990, № 3, s. $155-161$.

Kartlis tskhoureba, Tbilisi 2008.

Khosroshvili T., Mtatsmindis „mamadavitis” mokhatulobis taviseburebani, „Saqartvelos Sidzveleni” 2013, № 16, s. 198-213.

Kiknadze V., Erovnuli da sacatsobrio problematika meckhramete saukunis qarveli sasuliero mogvatseebis shemoqmedebashi, Tbilisi 2009.

Makuljević N., The "Zograph" Model of Orthodox Painting in Southeast Europe 1830-1870, „Balcanica” 2003, Issue 34.

Mgaloblishvili A., Abastumnis aleqsandre nevelis eklesiis moxatuloba, Akhaltsikhis da Tao-klarjetis eparqia, Tbilisi 2013. 
Mgaloblishvili A., Shiomgvimis monastris gmrtismshoblis midzinebis eklesiis mokhatulobas Tan dakavshirebuli ramdnime sakitkhi, „Saqartvelos Sidzveleni” 2009, № 13, s. 225-240.

Tsitsishvili M., Chogoshvili N., Qartuli mxatvroba, ganvitarebis istoria (XVIII-XIX saukuneebshi), Tbilisi 2013.

Tumanishvili D., Gzajvaredinze, Tbilisi 2008.

Virsaladze V., Rospis ierusalimskogo krestnogo monastira I portret shota rustaveli, Tbilisi 1973.

TAMAR KHOSRoshvili

\section{Visualised imperialism and national identity. Some examples of the church painting in Georgia between 1801 and 1918}

IN different periods, Christian wall paintings have visualised various attitudes towards programmes, images and iconographies that were closely linked with the religious identities of communities. Following the emergence of nationalism in Georgia in the mid-19 ${ }^{\text {th }}$ century, wall paintings of this period also began to respond to national identity. The chronological limits of this article are determined by crucial events in the history of the country, such as the conquest of East Georgia by the Russian Empire in 1801 and the proclamation of the independence of the Democratic Republic of Georgia in 1918. Between these two events, a number of church paintings was created throughout Georgia. Some of them fully intended to promote the Russian imperial identity and served to consolidate the power of the Empire over the conquered country. While others, reflected the ideas and aspirations of Georgian nationalism. They are very different from the medieval examples displaying a growing interest in national saints and the events of Christian Georgian history. This paper is focused on the most significant examples.

Keywords: art of the early modern period, Christian art, church wall paintings, Postcolonial studies, national revival. 